\title{
Decadal changes of the Western Arabian sea ecosystem
}

\author{
Sergey A. Piontkovski · Bastien Y. Queste
}

Received: 18 October 2015/Accepted: 25 January 2016/Published online: 16 February 2016

(C) The Author(s) 2016. This article is published with open access at Springerlink.com

\begin{abstract}
Historical data from oceanographic expeditions and remotely sensed data on outgoing longwave radiation, temperature, wind speed and ocean color in the western Arabian Sea (1950-2010) were used to investigate decadal trends in the physical and biochemical properties of the upper $300 \mathrm{~m}$. $72 \%$ of the 29,043 vertical profiles retrieved originated from USA and UK expeditions. Increasing outgoing longwave radiation, surface air temperatures and sea surface temperature were identified on decadal timescales. These were well correlated with decreasing wind speeds associated with a reduced Siberian High atmospheric anomaly. Shoaling of the oxycline and nitracline was observed as well as acidification of the upper $300 \mathrm{~m}$. These physical and chemical changes were accompanied by declining chlorophyll- $a$ concentrations, vertical macrofaunal habitat compression, declining sardine landings and an increase of fish kill incidents along the Omani coast.
\end{abstract}

Keywords Arabian Sea $\cdot$ Fish landings $\cdot$ Chlorophyll-a $\cdot$ Sea surface temperature

\section{Introduction}

As an acknowledged concept of the Large Marine Ecosystems, the Arabian Sea is recognized as a unique ecosystem within the Indian Ocean (Sherman and Alexander 1990) with very pronounced fluctuations in physical, chemical, and biological properties. Seasonal dynamics of the Arabian Sea have drawn interest from the international scientific community over the past 50 years; however there has been a paucity of studies in the last two decades due to logistical constraints. In terms of changes, the region exhibits strong seasonal dynamics in which monsoonal winds force periodic modes of ocean-atmosphere coupling with dominant annual and semiannual periods (Morrison et al. 1998). Ultimately, these modes of atmospheric and hydrophysical processes are reflected in corresponding fluctuations of biological productivity (Banse and English 2000; Barber et al. 2001). What is currently less understood, namely due to reduced sampling in the last 20 years, are dominant patterns of variability over decadal timescales.

S. A. Piontkovski $(\bowtie)$

College of Agricultural and Marine Sciences, Sultan Qaboos University, Al-Khod 123, P.O. Box 34, Muscat,

Sultanate of Oman

e-mail: spiontkovski@gmail.com

B. Y. Queste

Centre for Ocean and Atmospheric Sciences, University of East Anglia, Norwich, Norfolk NR4 7TJ, UK 
Srivastava et al. (2000) investigated decadal trends in cyclonic disturbances across the Arabian Sea and the Bay of Bengal from 1891 to 1997 and identified a significant decrease in the annual frequency of storms across both basins. The decrease in storm frequency was particularly pronounced from 1970 to the present. In parallel, Zveryaev (2002) recorded an increase in sea surface temperature over the last few decades resulting in decreased land-sea heat gradients and weaker low-level westerlies over the northern Indian Ocean.

Gomes et al. (2014) reported a gradual change in dominant phytoplankton species during algal blooms in the northern Arabian Sea. Diatom-dominated communities were replaced by the dinoflagellate, Noctiluca scintillans, since the early 2000s. The authors associate this shift in community composition to more frequent upwelling of hypoxic waters into the euphotic zone. Over the same period (1998-2012), a decadal declining trend in global pelagic ocean chlorophyll was evaluated by Gregg and Rousseaux (2014), with a reference to the north Indian Ocean as well. However, their time series were relatively short.

Empirical evaluation of regional decadal trends is important for their subsequent assimilation by threedimensional coupled physical-biogeochemical models which allow a multilateral understanding of physicalbiological interactions and accurate long-term forecasts to be achieved (Peňa et al. 2010; Francis et al. 2013). These models would clarify the causes of global and regional warming, expanding hypoxia, declining primary production of the open ocean and many other phenomena which are currently under investigation.

The main constraint to identifying variability of ocean properties on decadal timescales is the availability of a well quality controlled regional database. In our case, this database is focused around the western Arabian Sea and assembles data from all available oceanographic expeditions to the region. In the present paper we put together the main decadal trends identified for the western Arabian Sea over the past 50-60 years, highlighting the changes which occurred between the first and forthcoming second International Indian Ocean Expeditions (Snider, 1961; Intergovernmental Oceanographic Commission 2013). We also describe the ecological impacts of the physical and chemical changes observed over decadal timescales, particularly with respect to Omani fisheries.

\section{Materials and methods}

Atmospheric pressure, sea surface temperature, outgoing longwave radiation, zonal and meridional wind speed components were retrieved from the NCEP/NCAR reanalysis database (Kistler et al. 2001), which is a joint product from the National Center for Environmental Prediction (NCEP, USA) and the National Center for Atmospheric Research (NCAR, USA). The product represents gridded data from 1948 to the present time. Each variable was extracted to cover the region bounded by $10^{\circ} \mathrm{N}-26^{\circ} \mathrm{N}$ and $50^{\circ} \mathrm{E}-64^{\circ} \mathrm{E} .10 \mathrm{~m}$ wind speed, air temperature, water temperature, salinity, $\mathrm{pH}$, dissolved oxygen, nitrate and chlorophyll- $a$ concentrations, measured both in situ and remotely, were collected from 1950 to 2010 in a region previously mentioned.

The meridional wind component has a positive value when the wind is blowing from south to north. A south wind has a positive meridional constituent, while a north wind has a negative one. In case of zonal component, values are positive when the wind is blowing from west to east. Thus, a west wind has a positive zonal constituent while an east wind has a negative one.

The $\mathrm{pH}$ of seawater was measured by means of standard $\mathrm{pH}$-meters "pH-262", "pH-340" (Methods on hydrochemical investigations of the ocean 1978) and by using the spectrophotometric techniques (Clayton and Byrne 1993). In the latter case, the pHT of samples using m-cresol purple (mCP) was determined from $\mathrm{pH}_{\mathrm{T}}=\mathrm{pK}_{\mathrm{ind}}+\log [(\mathrm{R}-0.0069) /(2.222-0.133 \mathrm{R})]$, where $\mathrm{pK}_{\text {ind }}$ is the dissociation constant for the indicator, $[\mathrm{H}+]_{\mathrm{T}}=[\mathrm{H}+]+[\mathrm{HSO} 4-]$, and $\mathrm{R}\left(\mathrm{A}_{578} / \mathrm{A}_{434}\right)$ is the ratio of the absorbance of the acidic and basic forms of the indicator corrected for baseline absorbance at $730 \mathrm{~nm}$.

The major part of the onboard measured concentration of nitrates and dissolved oxygen came from the UK and USA expeditions with an appropriate description of chemical analysis given elsewhere (JGOFS 1996; JGOFS Protocols 1994). $72 \%$ of the data collected originates from US and UK expeditions (Table 1). The location and number of casts within a $2^{\circ}$ grid square of all 29,043 vertical temperature profiles is shown in Fig. 1. In order to evaluate decadal changes, these data were arranged in the form of time series or decadal subsets, from 1950 to 2010. Vertical profiles of physical and chemical parameters were smoothed by cubic spline (Craven and Wahba 1979). 
Table 1 Research vessels and cruises assembled and contributed to the historical database on CTD casts

\begin{tabular}{|c|c|c|c|}
\hline Country & Institution & $\mathrm{R} / \mathrm{V}$ name and cruise \# & Year \\
\hline UK & BODC & DISCOVERY(D10) & 1994 \\
\hline UK & BODC & DISCOVERY(D12) & 1994 \\
\hline UK & UKNO & DALYMPLE & 1960,1963 \\
\hline UK & UKNO & HYDRA & 1976, 1984 \\
\hline UK & UKNO & ROYAL NAVY NON-SURVEY VESSELS & 1960,1995 \\
\hline UKRAINE & MHI & MIKHAIL LOMONOSOV, 19 & 1966 \\
\hline UKRAINE & IBSS & PROFESSOR VODYANITSKIY, 30 & 1990 \\
\hline UKRAINE & YugNIRO & NAUKA & $1967-1980$ \\
\hline UKRAINE & YugNIRO & SKIF & $1969-1970$ \\
\hline USA & NODC & THOMAS G. THOMPSON (TTN-043) & 1995 \\
\hline USA & NODC & THOMAS G. THOMPSON (TTN-045) & 1995 \\
\hline USA & NODC & THOMAS G. THOMPSON (TTN-049) & 1995 \\
\hline USA & NODC & THOMAS G. THOMPSON (TTN-050) & 1995 \\
\hline USA & NODC & THOMAS G. THOMPSON (TTN-053) & 1995 \\
\hline USA & NODC & THOMAS G. THOMPSON (TTN-054) & 1995 \\
\hline USA & NODC & USCGC RELIANCE & 1961 \\
\hline USA & NODC & COMMANDANT ROBERT GIRAUD & 1961 \\
\hline USA & NODC & KNORR & 1995 \\
\hline USA & WHOI & ESSO AFRICA & 1976 \\
\hline USA & WHOI & ESSO GENEVA & 1976-1977 \\
\hline USA & WHOI & ESSO KAWASAKI & 1975-1977 \\
\hline USA & WHOI & ESSO WILHELMSHAVEN & 1976-1977 \\
\hline USA & WHOI & ESSO HONOLULU & 1976, 1979 \\
\hline USA & WHOI & ESSO MADRID & $1978-1977$ \\
\hline USA & US NAVY SHIPS OF OPPORTUNITY & NAVY SHIPS* & 1960, 1992 \\
\hline GERMANY & FM-GEOMAR & METEOR 32_1 & 1995 \\
\hline GERMANY & FM-GEOMAR & SONNE 89_1 & 1993 \\
\hline GERMANY & FM-GEOMAR & METEOR 32_4 & 1995 \\
\hline GERMANY & FM-GEOMAR & METEOR 32_6 & 1996 \\
\hline GERMANY & FM-GEOMAR & METEOR 74_3 & 2007 \\
\hline GERMANY & FM-GEOMAR & SONNE 118 & 1997 \\
\hline GERMANY & FM-GEOMAR & SONNE 119 & 1997 \\
\hline GERMANY & FM-GEOMAR & SONNE 120 & 1997 \\
\hline THE NETHERLANDS & $\mathrm{NIOZ}$ & TYRO, LEG D2 & 1992 \\
\hline THE NETHERLANDS & $\mathrm{NIOZ}$ & TYRO, LEG D3 & 1992 \\
\hline PAKISTAN & NIOPK & NASEER1 & 1992 \\
\hline PAKISTAN & NIOPK & NASEER2 & 1992 \\
\hline PAKISTAN & NIOPK & NASEER3 & 1993 \\
\hline PAKISTAN & NIOPK & NASEER4 & 1994 \\
\hline PAKISTAN & NIOPK & NASEER5 & 1994 \\
\hline JAPAN & JODC & UMITAKA MARU & 1994 \\
\hline CANADA & CANADIAN NAVY & ROYAL CANADIAN NAVY SHIPS & $2001-2005$ \\
\hline FRANCE & NHOS & BEAUTEMPS-BEAUPRE & 2004-2010 \\
\hline AUSTRALIA & AUSTRALIAN NAVY & ROYAL AUSTRALIAN NAVY SHIPS & $2001-2010$ \\
\hline OMAN & MSFC & COASTAL WATERS STATIONS & $2001-2010$ \\
\hline
\end{tabular}


Table 1 continued

\begin{tabular}{lllr}
\hline Country & Institution & R/V name and cruise \# & Year \\
\hline & FREE-DRIFTING PROFILING FLOATS & ARGO & $2002-2010$
\end{tabular}

* NAVY research vessels: MT MITCHELL, AYLWIN. BAINBRIDGE, BROWN, BROWNSON, BRUMBY, CAPODANNO, DECATUR, ESSEX, FANNING, HEWES, J., KITTY HAWK, LA SALLE. MOBILE BAY, MULLINNIX, NEW, NOA, PASSUMPSIC, EARY, R. E., PHARRIS, REQUISITE, SEMMES, STRIBLING, TANNER, USS GEORGE K. MACKENZIE, VALDEZ, VOGELGESANG, ARCO JUNEAU, KIRK, KOELSCH, LAWRENCE, MOALE, MONTGOMERY, E., PAUL, TAYLOR, AIRCRAFT, BERKELEY, HOLT, H. E., and SOMERS

Data on industrial and traditional landings from Omani fisheries are based on a sampling system established by the Oman-American USAID project (Mathews et al. 2001) and have been regularly collected by the Department of Fisheries Statistics. Data on annual landings of sardines in the Sea of Oman were taken from the annual reports published by the Ministry of Agriculture and Fisheries (Fishery Statistics Book 2010). Fisheries data were complemented by data on fish kill incidents along the Omani coast, available from the
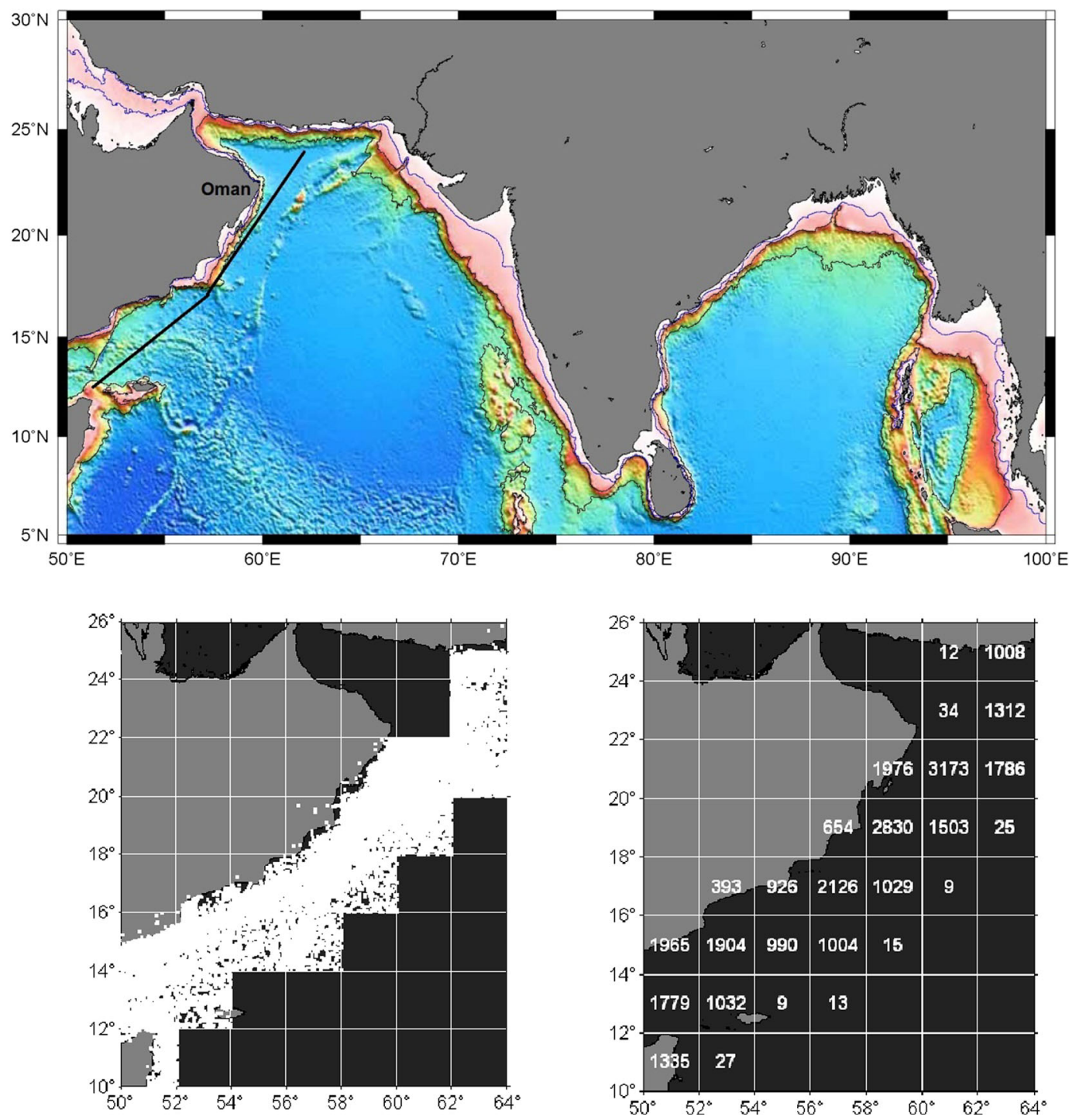

Fig. 1 Historical data and regions: (Upper panel) the map with the transect indicating the main axis of sampling sites near Oman; (Left low panel) location of oceanographic stations with vertical profiles of temperature (1950-2010); (Right low panel) actual number of CTD casts over $2^{\circ}$ squares 
archives of the Marine Science and Fisheries Research Center (Muscat, Oman) and published by Al-Gheilani et al. (2011).

\section{Results}

Atmospheric parameters

The outgoing longwave radiation (OLR) features the total radiation emitted by the atmosphere to space. It is believed that the OLR variations are affected by the Earth's skin temperature, atmospheric temperature, water vapor, and cloud cover (Susskind et al. 2011). Monthly time series were retrieved from NCEP database, in which they also stem from NCAR archives, with some missing values filled with temporal and spatial interpolation (Liebmann and Smith 1996). We used averaged values for January-February and July-August, to seek decadal trends of OLR during North-East and South-West monsoons (Fig. 2). Apparently, positive linear trends were pronounced for both seasons over five decades.

As far as the atmospheric pressure characteristics are concerned, the Siberian High acts as one of the dominant atmospheric pressure systems affecting winds over Asia and the northern Indian Ocean during North-East (winter) monsoon (Gong and Wang 1995; Gong and Ho 2002; Kim et al. 2005). Annual characteristics of Siberian High were kindly provided by R. (D'Arrigo et al. 2005). The anomaly is defined by the value above $1028 \mathrm{hPa}$ over the middle to higher Asia continent. The regression we elucidated implies a negative trend of the Siberian High index over the past five decades (Fig. 3). A Spearman rank correlation analysis of the annual time series of atmospheric pressure shows a negative correlation with sea surface temperature in winter (with $r=-0.4$, at $p<0.05$ ).

The wind field in our study was characterized by zonal and meridianal components of the wind speed (Fig. 4). A characteristic pattern pronounced in both components is a declining trend covering the time range from 1960 to 2010 .

Sea temperature

Two data sets were used to investigate long-term temperature trends: 60 year of SST from the NCEP-NCAR Reanalysis database and the historical database on vertical profiles of temperature we assembled for the

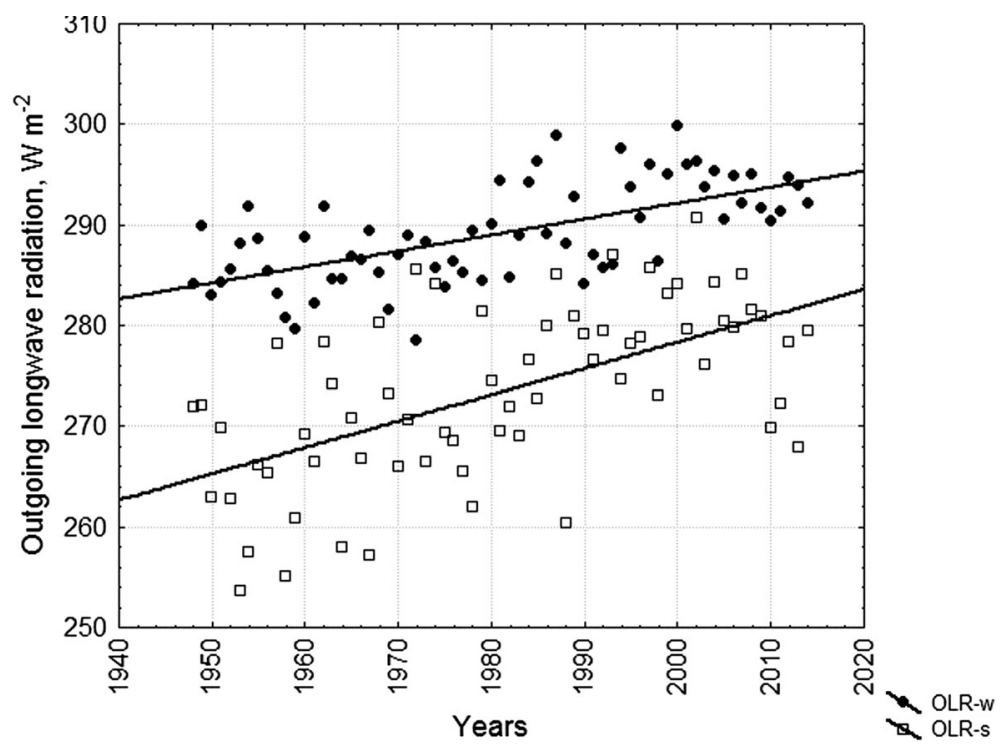

Fig. 2 Interannual changes of the outgoing longwave radiation in the western Arabian Sea during summer (OLR-s, averaged July-August) and winter monsoons (OLR-w, averaged January-February). Annual data for the period 1948-2014 retrieved from the NCEP-NCAR database 


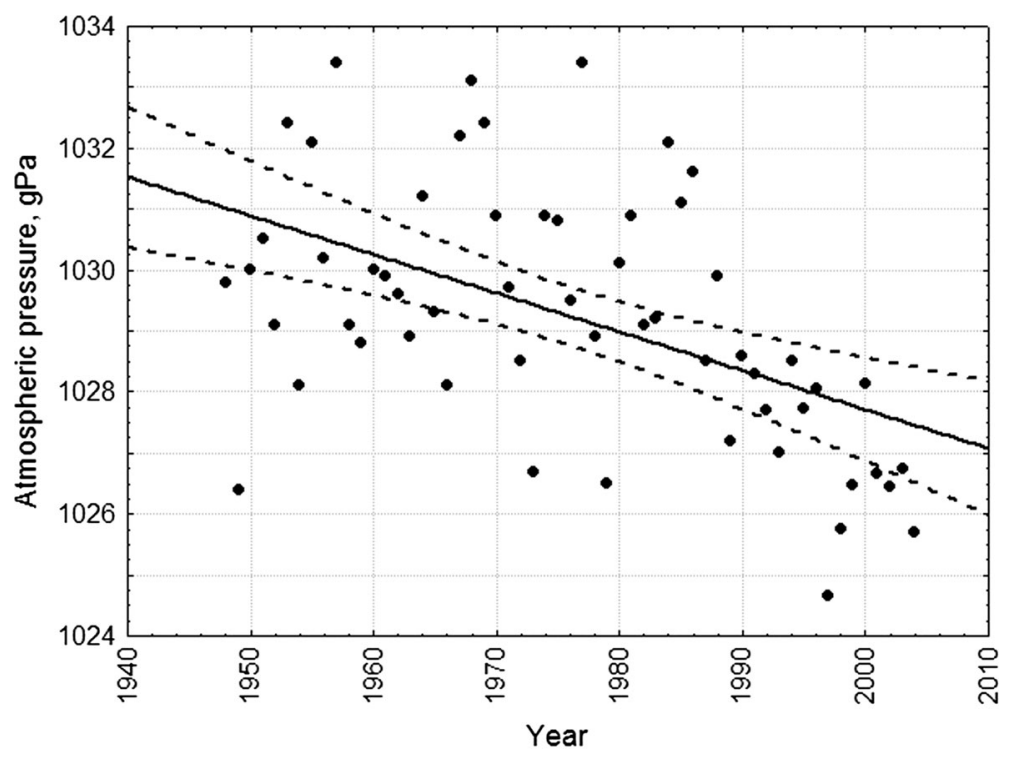

Fig. 3 Interannual changes of atmospheric pressure in the region of Siberian High (data from D'Arrigo et al. (2005). Regression parameters: $r=-0.5 ; p=<0.05$. Dashed lines are $95 \%$ confidence limits

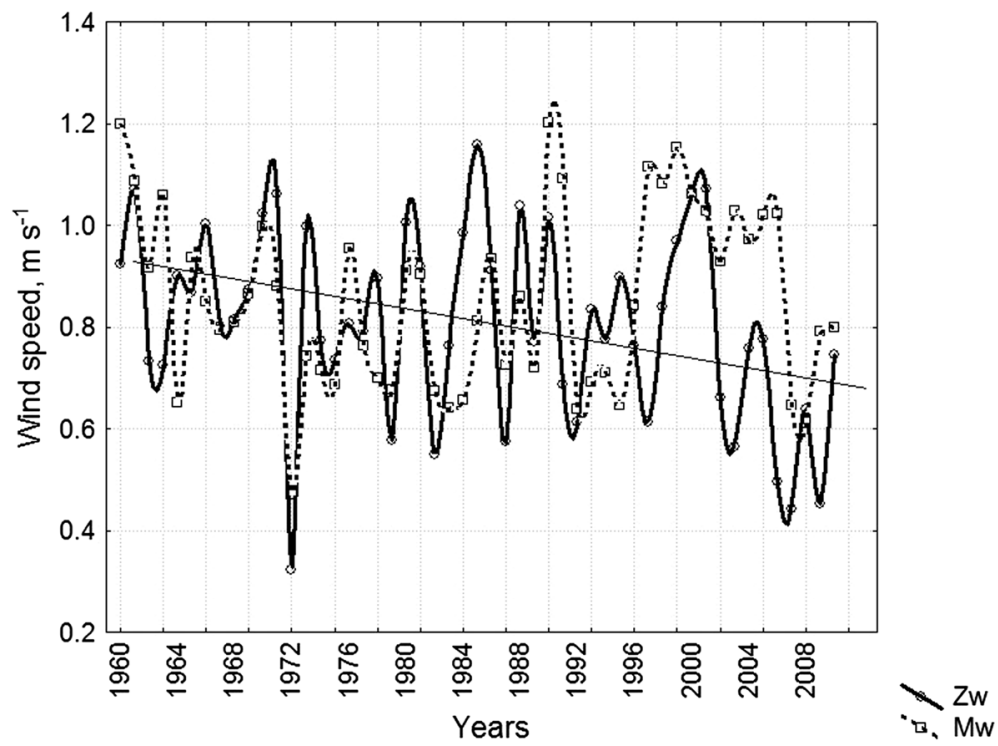

Fig. 4 Interannual changes of the wind speed in the western Arabian Sea; zonal ( $\mathrm{Zw}$ ) and meridianal components (Mw). Data were retrieved from the NCEP-NCAR database. Curves were smoothed by cubic spline

region. According to NCEP-NCAR data, decadal changes of the sea surface temperature in the western Arabian Sea during the South-West Monsoon can be characterized by a positive trend of $0.2{ }^{\circ} \mathrm{C}$ per decade $(r=0.5, p<0.05)$.

In the western Arabian Sea, the surface mixed layer extends to $\sim 30 \mathrm{~m}$ with a seasonally variable in depth thermocline extending below. The thermocline layer is underlied by the Persian Gulf Water Mass which originates in the Persian Gulf and flows out through the Strait of Hormuz. Persian Gulf Water Mass outflow is mediated by the atmospheric pressure gradient between the Gulf and the Sea of Oman (Yao and Johns 2010). This water mass propagates eastwards between 150 and $350 \mathrm{~m}$ to the western Arabian Sea. The decadally averaged temperature profiles show a gradual warming of the entire water column with no change in mixed layer depth (Fig. 5). The rate of warming in the upper $30 \mathrm{~m}$ layer is approximately $0.6{ }^{\circ} \mathrm{C}$ per decade $(r=0.8$, $p<0.1)$. Warming at depth is less pronounced with rates approaching $0.4{ }^{\circ} \mathrm{C}$ per decade $(r=0.8, p<0.1)$. 


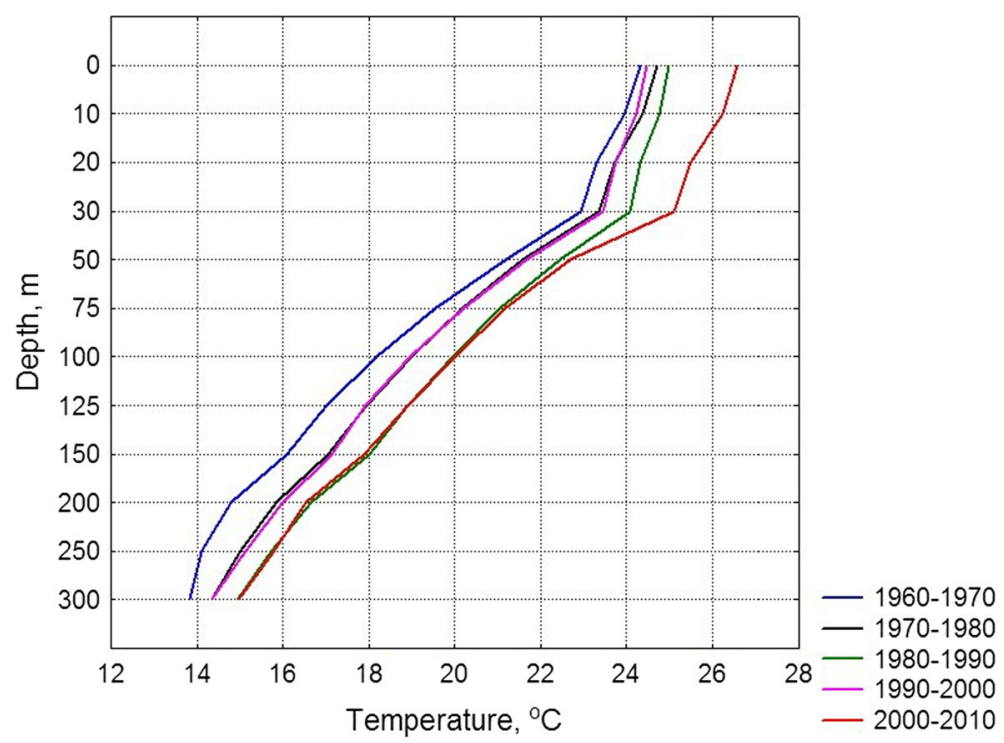

Fig. 5 Vertical profiles of summer temperature in the western Arabian Sea (b), averaged over decades

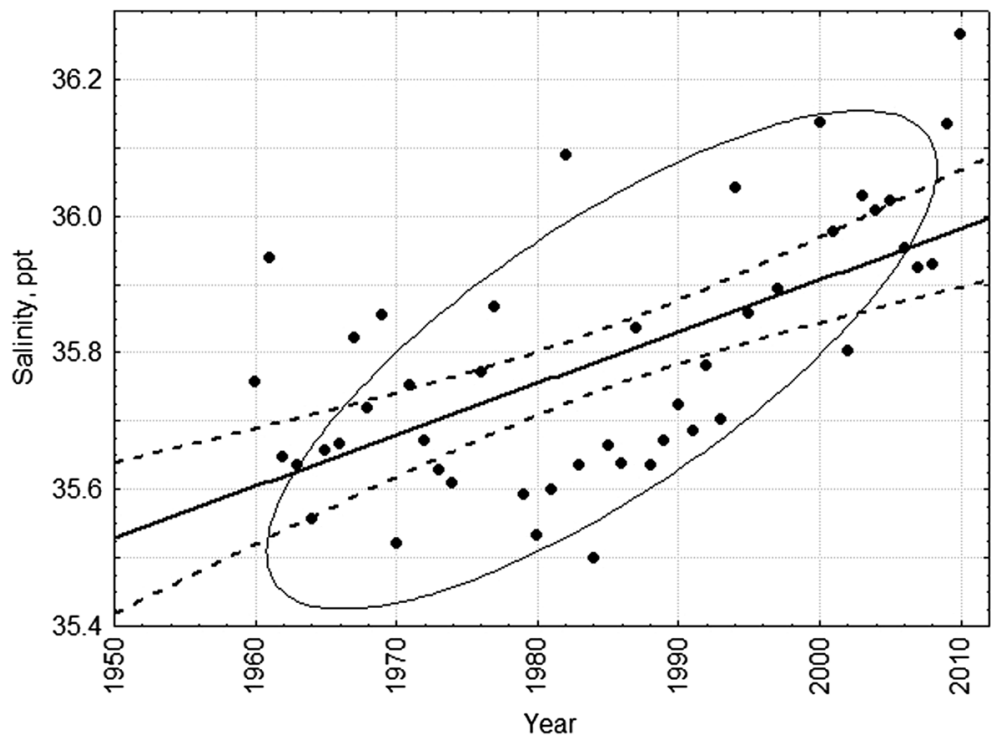

Fig. 6 Interannual changes of salinity at a $300 \mathrm{~m}$ depth. Regression parameters: $Y=2.82+0.0075 \mathrm{X}$; Number of annually averaged measurements: $n=676, r=0.62, p<0.05$. Dashed lines are $95 \%$ confidence limits. The correlation ellipsis and regression curve are given by solid lines

\section{Salinity}

No decadal trends in upper mixed layer salinity were pronounced, however changes were observed at depth. A characteristic feature of the western Arabian Sea is the presence of warmer high salinity waters originating in the Persian Gulf and forming the Persian Gulf Water Mass which resides at depths of 150-350 m (Fig. 6). Changes in salinity at this depth are indicative of varying Persian Gulf Water properties or flow. We investigated decadal changes of salinity at a $300 \mathrm{~m}$ depth. The data indicate increased Persian Gulf Water Mass outflow during the past five decades as illustrated by the warming and increasing salinity of 0.3 signatures between 200 and $300 \mathrm{~m}$ (Figs. 5, 6). 


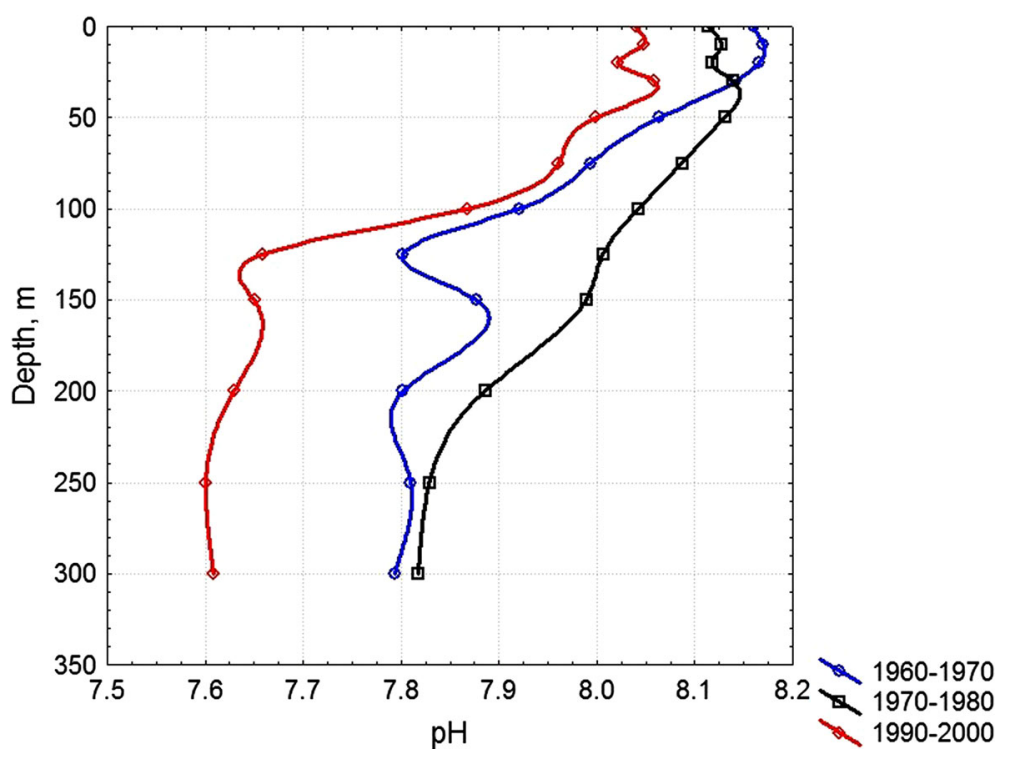

Fig. 7 Decadal changes of the pH vertical distribution in the western Arabian Sea. Curves were smoothed by cubic spline. Number of stations per decade: $n=38$ (1960-1970); $n=28$ (1970-1980); $n=43(1990-2000)$

$\mathrm{pH}$

In situ measurements of $\mathrm{pH}$ were much less numerous compared to vertical profiles of temperature and salinity. Only 38 oceanographic stations included pH measurements between 1960 and 1970, 28 between 1970 and 1980, and 43 stations for 1990-2000. Vertical profiles were averaged annually first, then over a decade, to calculate the decadal profile. The data indicate an overall decrease in $\mathrm{pH}$, particularly at depth. However due to the paucity of data, it is not possible to state that this trend is significant and not an artifact linked to temporally biased sampling (Fig. 7). Over the past 40 years, $\mathrm{pH}$ has diminished by 0.2 units in the upper $50 \mathrm{~m}$ layer $(\mathrm{df}=22, t=1.76 ; p=0.1)$. Acidification rates derived from these profiles are $0.1 \mathrm{unit} \mathrm{pH}$ per decade.

\section{Dissolved oxygen}

2117 dissolved oxygen profiles were averaged over each decade (Fig. 8). They indicated a gradual shoaling of the oxycline. For instance, the depth of the $1 \mathrm{ml} \mathrm{L}^{-1}$ concentration located at $\sim 145 \mathrm{~m}$ in $1960-1990$ has shifted to $\sim 80 \mathrm{~m}$ in 1990-2010. The shoaling of the oxycline was verified by a $t$ test showing statistically significant inter-decadal differences between vertical profiles, in particular the "oldest" and the "newest" (Table 2).

\section{Nitrates}

Data for the concentration of dissolved nitrates came from various expeditions cited in Fig. 1 and Table 1. Nitrate measurements require a specific sampling program and are therefore less numerous. The 1960-1970 decade contained 145 stations, 1970-1980 had 18 stations and 1990-2000 had 305 stations. Decadal mean profiles imply a decline in nitrate concentrations in the upper $30 \mathrm{~m}$ layer above the seasonal thermocline (Fig. 9). This decline has consisted of about $30 \%$, comparing the oldest versus the latest profiles (1960-1970 versus the 1990-2000). Both decades are relatively well fitted by measurements, with 81 and 76 vertical profiles correspondently. The concentration decline in the upper $30 \mathrm{~m}$ layer has consisted of $31 \%$, comparing the oldest versus the latest decadal profiles. 


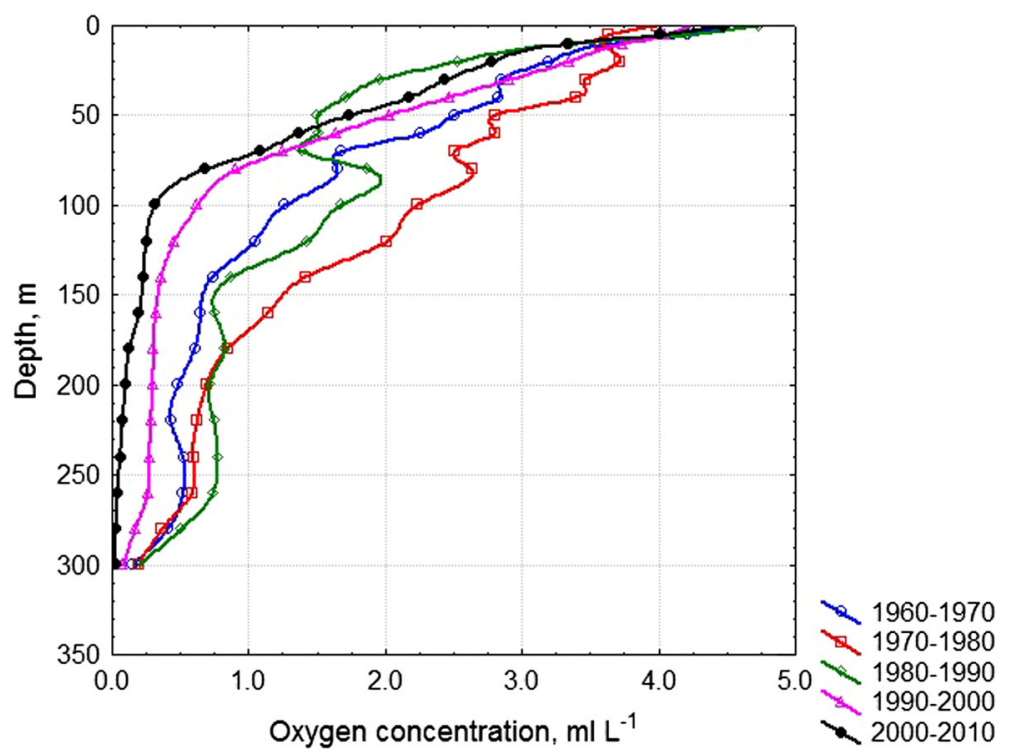

Fig. 8 Decadal changes of the dissolved oxygen vertical profiles in the western Arabian Sea during the South-west Monsoon season. Curves were smoothed by cubic spline

Table 2 Comparative statistics for the decadal profiles of dissolved oxygen concentration. $N$ is the number of layers in the vertical profile, " $t$ " is the $t$ value, "df" is the degree of freedom, and " $p$ " is the probability level

\begin{tabular}{llrrr}
\hline Decade & $N$ & $t$ & $d f$ & $p$ \\
\hline 1960 s vs 1970s & 21 & -3.48 & 20 & 0.0024 \\
1970 s vs 1980s & 21 & 2.87 & 20 & 0.0095 \\
1990 s vs 2000s & 21 & 5.94 & 20 & $<0.0001$ \\
1960 s vs 2000s & 21 & 8.89 & 20 & $<0.0001$ \\
\hline
\end{tabular}

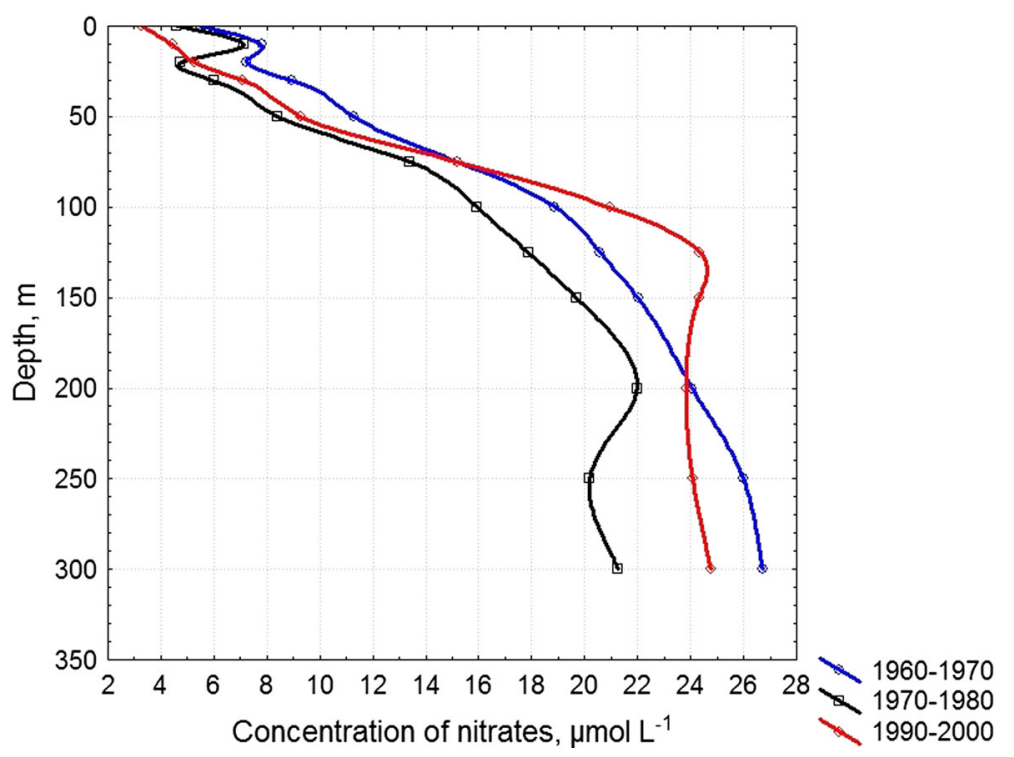

Fig. 9 Decadal changes of annually averaged vertical profiles of the concentration of nitrates in the western Arabian Sea. Curves were smoothed by cubic spline. The number of stations per decade: $n=145(1960-1970) ; n=18(1970-1980) ; n=305$ (1990-2000) 
Chlorophyll "a"

Remotely sensed chlorophyll- $a$ concentrations from the SeaWIFS scanner enabled us to analyze the time range from 1997 to 2010 only. The time series from 2002 to 2014 is available from the MODIS scanner. Both are too short to undertake an analysis over decadal timescales. The SeaWIFS time series revealed typical fluctuations of chlorophyll concentration with a dominant period of 1 year and 6 months (Piontkovski and Claereboudt 2012; Piontkovski et al. 2013). We observed a slight negative trend in chlorophyll- $a$ concentrations interannualy. We also identified a strong negative correlation between sea surface temperature (Y) with chlorophyll values (X) obtained for the western Arabian Sea (Piontkovski et al. 2013): $Y=7.41-0.23 \mathrm{X}$ $(r=-0.5, p<0.05)$. Sea surface temperatures for the region were retrieved from the NCEP-NCAR database.

Further on, the sea surface temperature was averaged for summer months for each year and correspondently (using the above mentioned equation linking sea surface temperature with chlorophyll), we obtained the chlorophyll concentrations characterizing the time of the South-west Monsoon (summer monsoon). A decadal trend was well pronounced in the retrieved time series (Fig. 10). The chlorophyll concentration has declined by about $40 \%$, from 1950s to 2010 .

Fish landings (sardines and large pelagics)

Historical data on Omani fisheries go back to 1980s and ranked by several categories entitled in archived materials as "Large pelagics", "Small pelagics", "Demersal", "Unidentified Fishes", and etc. Within these categories, fish are distributed in groups such as "Barracuda", "King Fish", "Queenfish", "Sardines", etc. Sardines have dominated small pelagic fish catches over the Omani shelf. Approximately $80 \%$ of artisanal landings within this group are contributed by the Indian oil-sardine Sardinella longiceps (Al-Abdessalaam 1995).

We retrieved monthly values and compiled data in the form of landings over the Arabian Sea, the Sea of Oman, and total Omani landings (Fig. 11). The time series obtained appeared to be relatively short. However, even in the range of the last two decades, one could observe a tendency of sardine catches to decline, over the Omani coast. In terms of decadal changes, a general decline of the magnitude of seasonal fluctuations might be observed. These fluctuations were much more pronounced in the 1990s compared to the next decade. Unfortunately, we were forced to construct the monthly time series by starting from 1994, because archived data from the 1980s were full of missed values.

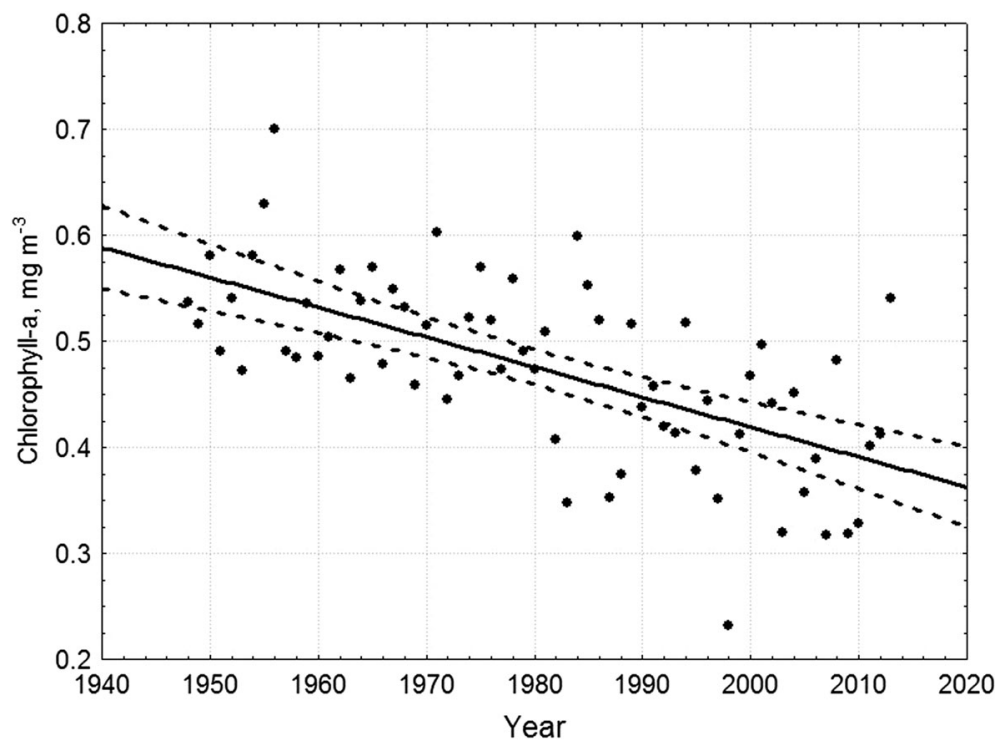

Fig. 10 Decadal changes of the chlorophyll- $a$ concentration in the surface layer $(Y=6.06-0.003 \mathrm{X} ; r=-0.6 ; p<0.05)$. Dotted lines are $95 \%$ confidence limits 
Being intensive consumers of phytoplankton in Omani waters (Haleem et al. 2011), through fluctuations of landings, sardines demonstrate a positive correlation with monthly fluctuations of chlorophyll- $a$ concentrations (Piontkovski et al. 2014). As for the chlorophyll- $a$ concentration itself, we showed that this parameter has exhibited a declining decadal trend (Fig. 10).

Data on fish landings, despite their known errors and biases have been commonly used to infer associations between fish and their environment (Sundermeyer et al. 2005; O'Brien and Rago 1996). We analyzed interannual fluctuations of Yellowfin tuna and sardine landings. Being a planktivorous fishes, sardines are hunted down by large pelagic species such as the Yellowfin tuna. These trophic interactions dominate in the upper layer and are visible in landing statistics (Fig. 12). One could denote the fluctuations close to an inverted type, featuring the "Predator-Prey" interactions over the past 14 years. In this particular case, landing values might be treated as indicators of population abundance: a rising abundance in the population of predator

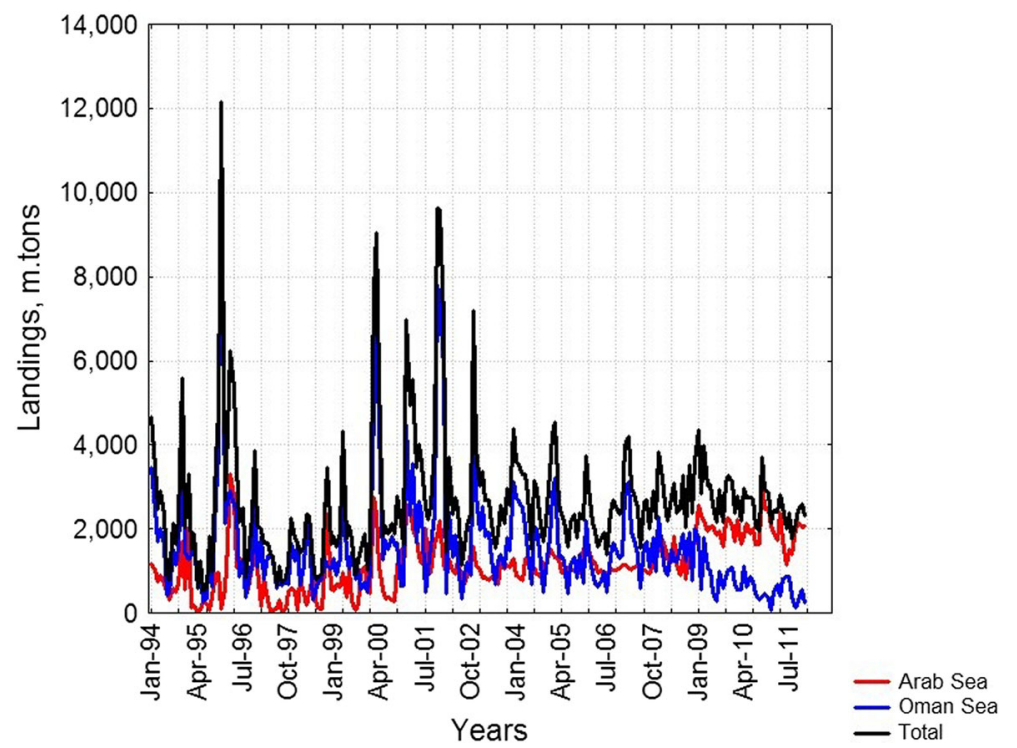

Fig. 11 Monthly fluctuations of sardine landings along the Omani shelf (the Arabian Sea, the Sea of Oman, and the total landing by the sate)

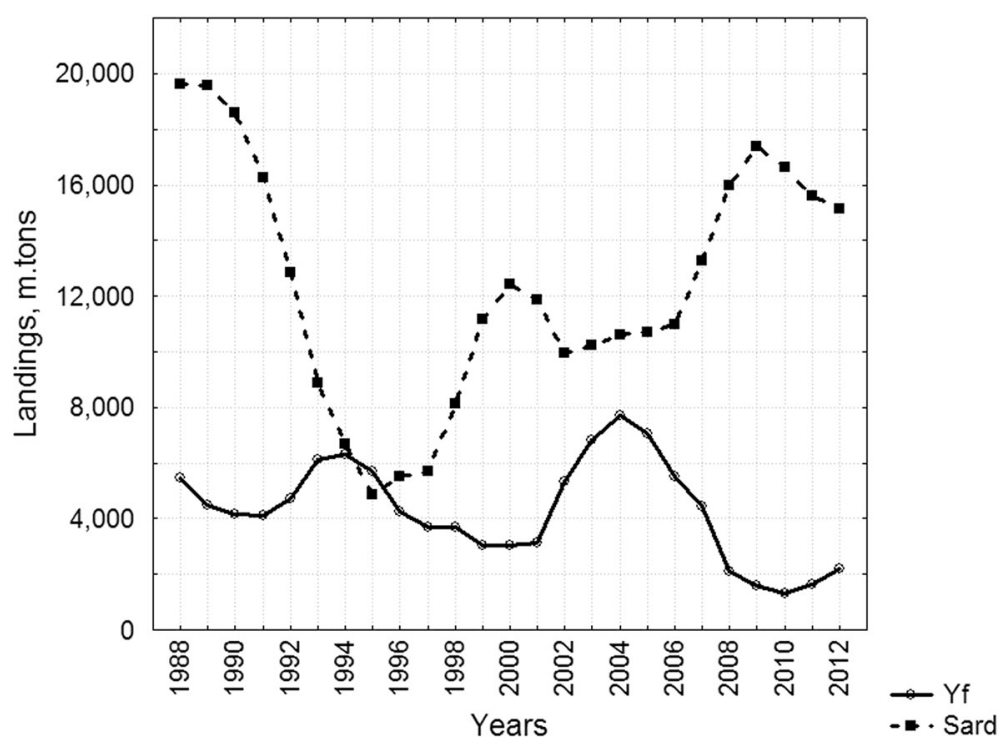

Fig. 12 Annual landings of Yellowfin tuna (Yf) and sardines (Sard) in the Arabian Sea. Time series were smoothed by the 3 year running mean 
results in a decline of the prey population, and vice versa: a minimum in the abundance of predator is the time range for the population of prey to increase; exhibited by the plot. Interestingly, we did not find a similar type of the "Predator-Prey" interaction to be pronounced in landings of Yellowfin tuna in other subtropical regions, like southern latitudes of the western Indian Ocean, near Mauritius island (Dhurmeea et al. 2012) in which the oxycline is deepened, compared to the north-western Arabian Sea shelf.

Variability in Persian Gulf Outflow greatly influences the depth of the oxycline and thought that available vertical habitat for each species. It is possible that the fluctuations observed here are also affected by temporal patterns of habitat compression in the Sea of Oman.

Fish kills

The early records on fish kill incidents along the Omani coast overlooking the western Arabian Sea are date back to the mid 1970s. Since then, monitoring of algal blooms and fish kill incidents has been carried out by the Ministry of Agriculture and Fisheries at several points along the $\sim 3000 \mathrm{~km}$ of the Omani coast. Records exhibit a threefold increase in the frequency of fish kill incidents (Fig. 13). In this regard, the latest decade appeared to be the most dramatic. Overall, the main contributors to fish kills were small pelagic fishes. Part of fish kills were observed during algal blooms, but also related to warm low oxygenized waters (Al-Gheilani et al. 2011).

\section{Discussion}

Linear (decreasing or increasing) decadal trends appeared to be well pronounced in a number of key environmental parameters characterizing the western Arabian Sea. In the Oman region, decadal changes in tropical rainfall and monsoon intensity are strongly related to variations in solar radiation (Neff et al. 2001). We observed positive trends in longwave radiation, air temperature at sea surface, and sea surface temperature. These trends were underlied by decadal declining trends of wind speed which in turn could be associated with a declining trend of the Siberian High atmospheric anomaly (Fig. 3). For instance, Panagiotopoulos et al. (2005) reported a statistically significant positive correlation between Siberian High and upper air zonal wind. Joseph and Xavier (1999) found a prominent linear decreasing trend in the frequencies of summer monsoon depressions, for the period of 1891-1998 (108 years).

A remote control partially mediating the atmospheric processes over the Arabian Sea region has been highlighted by a number of studies. Burns et al. (2002) reported decreasing monsoonal rainfall over the past century related to increasing sea surface temperature in the Indian Ocean. They concluded that decadal to

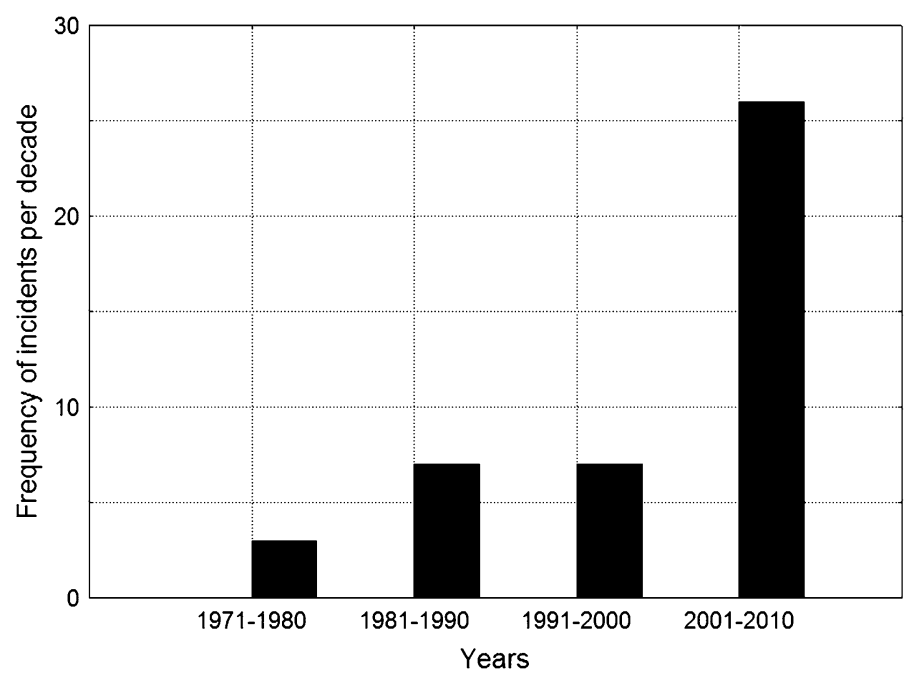

Fig. 13 Decadal changes of the frequency of fish kill incidents over the Omani coast 
interannual cycles in their data appeared to originate in the tropical Pacific Ocean. For instance, the El-Niňo Southern Oscillation in the Pacific and the Indian Ocean Dipole in the southern tropical latitudes of the Indian Ocean both could contribute in part to long-term changes of sea surface temperature (Eremeev et al. 2012; Saji et al. 1999).

Warming of the water mass should theoretically result in increased acidification (Chierici and Fransson 2009). Both trends match this notion, in the aspect of decadal changes in the studied region. In analyzing decadal changes of salinity at a $300 \mathrm{~m}$ depth, we pointed out that not only the Persian Gulf Water Mass got warmer over past five decades; it also got saltier. This shelf-related phenomenon has its basin scale extension; salinity increase was reported for 1950-2008 in the poorly ventilated deep north Indian Ocean in the range of densities driven by the Red Sea Water mass and the Gulf Water mass (Durack and Wijffels 2010; Tomzac and Godfrey 1994).

Hypoxia is generally defined as $<2 \mathrm{mg} \mathrm{O}_{2} \mathrm{~L}^{-1}$ (Gray et al. 2002). In the western Arabian Sea, hypoxic zones over the shelf and eastwards, towards the oceanic regions, were reported for various seasons and were studied primarily in regards to seasonal changes (Herring et al. 1998; Morrison et al. 1998). We observed both a shoaling of the oxycline and general decline of oxygen concentrations in the upper mixed layer. From this, we speculate that both processes are mediated in part by basin scale zonal and meridianal advection of water masses. For instance, in the Arabian Sea, the phenomenon of zonal advection by the western boundary current was reported by Resplandy et al. (2012). The other potential contributor to the declining trend is the frequency of occurrence of mesoscale cyclonic eddies shifting oxycline upward. The western Arabian Sea is known for its vigorous eddy field denoted by high packed cyclonic and anticyclonic eddies (Piontkovski and Al-Jufaili 2013). However, the time range enabling the decadal trend of eddy occurrence to be statistically assessed is still short for the region.

The Persian (Arabian) Gulf mediates, in part, the acidification of the north-western Arabian Sea, through horizontal advection of waters with high salinity and low $\mathrm{pH}$ values. A declining trend of $\mathrm{pH}$ reported for the Gulf in 2007-2010 (Uddin et al. 2012) is a regional fragment contributing to the basin scale phenomenon we discussed. The acidification rate we obtained (Fig. 7), has exceeded the ones reported for the other tropical and subtropical regions, i.e. during the BATS time series in the subtropical Atlantic and HOTS-Hawaiian time series in the subtropical Pacific Ocean (Doney et al. 2009), although these time series did not span the range of five decades. A pH time series of similar duration (1940-1999) was investigated recently by Shinjo et al. (2013). They provided insights into boron-isotope composition $(\delta 11 \mathrm{~B})$ in massive Porites coral from Guam Island (in the North-western tropical Pacific). Interannual data showed a decreasing trend equivalent to $\sim 0.05-0.08 \mathrm{pH}$ units for surface water $\mathrm{pH}$.

Decadal vertical profiles of temperature pointed to a mean increase of $2.26 \pm 0.91{ }^{\circ} \mathrm{C}$ at surface and $1.15 \pm 0.48{ }^{\circ} \mathrm{C}$ at a depth of $300 \mathrm{~m}$-both during summer period, from 1960s to 2010 (Fig. 5). The mean warming we observed over the past 60 years has exceeded the values reported for the near surface warming of the World Ocean (Gouretski et al. 2012); this highlights that regional trends do not necessarily reflect global trends. Perhaps the land-locked nature of the Arabian Sea, with no northward water mass transport contributes to a pronounced warming trend. Overall, the stratification of the water column has become more pronounced in the past 5 decades. Through increasing vertical gradient of temperature, this could contribute to a reduction of dissolved nitrate observed in the upper $30 \mathrm{~m}$ layer (Fig. 9). This would have direct ecological consequences; it is believed, excepting the South-West monsoon season, the concentration of nitrates in the upper layer could limit primary production (McCarthy et al. 1999) — the phenomenon reflected in part by a declining decadal trend of chlorophyll- $a$ concentration (Fig. 10).

All in all, this suggests that the decadal trends we discussed are coupled. The weakening of the Siberian High atmospheric anomaly (Fig. 3) might be one of the reasons for the decline of wind speed (Fig. 4) and correspondent increase in atmospheric temperature. This in turn increases the temperature in the mixed layer, strengthening the thermohaline stratification of the water column (Fig. 5). More stratified conditions then reduced the penetration of nutrients into the upper mixed layer (Fig. 9). This would in turn affect primary production (assessed generally by the chlorophyll- $a$ concentration, Fig. 10) and higher trophic levels (Fig. 11). Simultaneously, the size of high productive zones in the western Arabian Sea has decreased (Piontkovski and Claereboudt 2012; Piontkovski et al. 2013).

These environmental and habitat changes could also set up favorable conditions for some species to proliferate. For instance, there is a belief that in the past decade, the dinoflagellate Noctiluca scintillans has 
expanded markedly over the Arabian Sea. Large blooms of this species were reported in the eastern and western Arabian Sea (Gomes et al. 2014). Noctiluca prefers higher temperatures, calmer waters, and is more competitive in oxygen depleted waters (Gomes et al. 2014). This is in agreement with the observed trends in environmental conditions. Expanding blooms of $N$. scintillans may also partially explain the declining trend in chlorophyll- $a$ concentrations (Fig. 10) as the species is a mixotrophic organism actively consuming phytoplankton. This correlation has previously been reported in the literature (Huang and Qi 1997).

More stratified conditions, along with acidification of the upper $300 \mathrm{~m}$ layer (Fig. 7), shoaling of the oxycline (Fig. 8) and declining oxygen concentrations will directly contribute to increasing fish kill incidents (Fig. 13) and habitat compression for pelagic fishes over Omani shelf. This habitat compression is likely the cause of the reduced variability in sardine landings (Fig. 11). Oxygen concentrations below $3.5 \mathrm{ml} \mathrm{L} \mathrm{L}^{-1}$ are stressful for many larger tropical pelagic fish (Prince and Goodyear 2006; Stramma et al. 2012). Oxygen and a shoaling oxycline both result in pelagic populations compressed in the upper layer. This increases they susceptibility to trawling and traditional fishing practices. Consequently, artisanal landings of pelagic species in Oman are tightly linked to hydrophysical processes and their changes over the last 50 years. Landings for 13 major groups of large pelagic species (Yellowfin tuna, Longtail tuna, Kawakawa, Stripped bonito, Frigate tuna, Other tuna, Skipjack, Kingfish, Queenfish, Baracuda, Cobia, Sailfish, and Large jacks) displayed positive trends through the past 20 years (Fishery Statistics Book 2012). However, rising landings (markedly driven by increased number of boats) might end soon. A shoaling oxycline (Fig. 8) could reach an ecological threshold of oxygen depletion in the upper $50 \mathrm{~m}$ layer, pushing hypoxic waters further onto the Omani shelf in the coming decades. Further shoaling could cause a gradual decline or even a collapse of large pelagic fisheries as many species will move offshore. This is a critical issue as the artisanal fishery, accounting for $96 \%$ of Omani landings, represents the cornerstone of the national industry, directly employing around 40,000 fishermen (Fishery Statistics Book 2012; Piontkovski et al. 2014).

At the same time, the amplitude of interannual changes is greater than that of decadal trends and our observations based on limited data. It is still possible that these conditions could be reversed in the coming decade. A decadal variation of atmospheric processes (like the intensity of Indian Ocean monsoonal winds) could be mediated by extra-terrestrial forces; for instance, lunar tidal actions which have the periodicity of 56, 95, 125 and 1470 years (Von Rad et al. 2006). These cycles were detected in some characteristics of sediment cores extracted from the Oxygen Minimum Zone of the Pakistan shelf. However, fluctuations of physical, chemical and biological processes of the Arabian Sea on the scale of hundreds of years are poorly understood so far.

\section{Conclusion}

In studying the western Arabian Sea, the following decadal trends were noticed, over the past 50 years (1960-2010): (1) decline of the wind speed associated with correspondent decline in the pronouncement of the Siberian High atmospheric anomaly, (2) increase of the atmospheric temperature at sea surface, water salinity and sea temperature in the upper $300 \mathrm{~m}$ layer, (3) intensive shoaling of the oxycline and nitracline, (4) intensive acidification of the water column, and (5) a decline of the concentration of dissolved nitrates.

Biological phenomena associated with and driven in part by the above decadal trends of physical-chemical processes were as follows: (1) compression of pelagic fish habitats and their progressive stratification due to increasing thermo-haline and oxygenic stratification in the upper $300 \mathrm{~m}$ layer, (2) a decline in the chlorophylla concentration (an indicator of biological productivity), (3) a decline of sardine landings over some regions, and (4) an increase of fish kill incidents.

Eventually, the economic and social consequences of these trends might result in a gradual decline or even a collapse of large pelagic fisheries; many species will move offshore because of intensive shoaling of the oxycline. The artisanal fishery, accounting for $96 \%$ of Omani landings and directly employing around 40,000 fishermen would face problems.

Acknowledgments This work was supported by the Research Council Grant \# ORG/EBR/11/002 and ONR GLOBAL Grant \# N62909-14-1-N224. The authors would like to thank L.Galkovskaya for technical assistance with the database compilation. 
Open Access This article is distributed under the terms of the Creative Commons Attribution 4.0 International License (http:// creativecommons.org/licenses/by/4.0/), which permits unrestricted use, distribution, and reproduction in any medium, provided you give appropriate credit to the original author(s) and the source, provide a link to the Creative Commons license, and indicate if changes were made.

\section{References}

Al-Abdessalaam TZS (1995) Marine species of the Sultanate of Oman. Mar Sci Fish Cent Minist Agr Fish Sultanate of Oman, Pub.46/95, pp 412

Al-Gheilani HM, Matsuoka K, Al Kindi K, Amer S, Waring C (2011) Fish kill incidents and harmful algal blooms in omani waters. Agr Mar Sci J 16:23-33

Banse K, English DC (2000) Geographical differences in seasonality of CZCS-derived phytoplankton pigment in the Arabian Sea for 1978-1986. Deep Sea Res II 47:1623-1677

Barber RT, Marra J, Bidigare R, Codispoti L, Halpern D, Johnson Z, Latasa M, Goerìe R, Smith S (2001) Primary productivity and its regulation in the Arabian Sea during 1995. Deep Sea Res II 48:1127-1172

Burns SJ, Fleitmann D, Mudelsee M, Neff U, Matter A, Mangini A (2002) A 780-year annually resolved record of Indian Ocean monsoon precipitation from a speleothem from south Oman. J Geophys Res 107(D20):4434. doi:10.1029/2001JD001281

Chierici M, Fransson A (2009) Calcium carbonate saturation in the surface water of the Arctic Ocean: undersaturation in freshwater inuenced shelves. Biogeosci 6:2421-2432

Clayton TD, Byrne RH (1993) Spectrophotometric seawater pH measurements: total hydrogen ion concentration scale calibration of $m$-cresol purple and at-sea results. Deep Sea Res I 40:2115-2129

Craven P, Wahba G (1979) Smoothing noisy data with spline functions: estimatimg the correct degree of smoothing by the method of generalized cross-validation. Numer Math 31:377-403

D’Arrigo R, Jacoby G, Wilson R, Panagiotopoulos F (2005) A reconstructed Siberian High index since A.D. 1599 from Eurasian and North American tree rings. Geophys Res Lett 32:L05705. doi:10.1029/2004GL022271

Dhurmeea Z, Beeharry SP, Sooklall T (2012) Catch/effort and length-frequency data on albacore tuna landed in Mauritius. Indian Ocean Tuna Comission-Working Party on Temperate Tunas. WPTmT04-12. http://www.iotc.org/documents/catch-effortand-length-frequency-data-collected-albacore-tuna-landed-mauritius. Accessed 3 Aug 2012

Doney SC, Fabry VJ, Feely RA, Kleypas JA (2009) Ocean acidification: the other $\mathrm{CO}_{2}$ problem. Ann Rev Mar Sci 1:169-192

Durack PJ, Wijffels SE (2010) Fifty-year trends in global ocean salinities and their relationship to broad-scale warming. J Clim 23:4342-4362

Eremeev VN, Jukov AN, Lebedev NE, Piontkovski SA, Sizov AA (2012) Interannual fluctuations of the atmospheric pressure, sea surface temperature, and chlorophyll- $a$ of the Arabian Sea. Int J Remote Sens 6(2):83-93

Fishery Statistics Book (2010) Ministry of fisheries wealth. Sultanate of Oman, Muscat, p 180

Fishery Statistics Book (2012) Ministry of fisheries wealth. Sultanate of Oman, Muscat, p 205

Francis PA, Vinayachandran PN, Shenoi SSC (2013) The Indian Ocean forecast system. Curr Sci 104(10):1354-1368

Gomes HR, Goes JI, Motondkar SGP, Buskey EJ, Basu S, Parab S, Thoppil P (2014) Massive outbreaks of Noctiluca scintillans blooms in the Arabian Sea due to spread of hypoxia. Nat. doi:10.1038/ncomms5862

Gong DY, Ho CH (2002) The siberian high and climate change over middle to high latitude. Theor Appl Climatol 72:1-9

Gong DY, Wang SW (1995) Long-term variability of the Siberian High and the possible influence of global warming. Acta Geogr 4:125-133

Gouretski V, Kennedy J, Boyer T, Köhl A (2012) Consistent near-surface ocean warming since 1900 in two largely independent observing networks. Geophys Res Lett 39:L19606. doi:10.1029/2012GL052975

Gray JS, Shiu-Sun R, Or YY (2002) Effects of hypoxia and organic enrichment on the coastal marine environment. Mar Ecol Progr Ser 238:249-279

Gregg WW, Rousseaux C (2014) Decadal trends in global pelagic ocean chlorophyll: a new assessment integrating multiple satellites, in situ data, and models. J Geophys Res. doi:10.1002/2014JC010158 (Accessed 20 Sep 2014)

Haleem SZA, Jayabalan N, Al-Kiyumi F, Al-Kharusi L, Al-Habsi S, Al-Marzouqi A (2011) Fishery, biology and population dynamics of three small pelagic fish species (Indian oil sardine Sardinella longiceps, Indian mackerel Rastrelliger kanagurta and Indian scad Decapterus russeli) from the Sultanate of Oman. Mar Sci Fish Cent Minist Agr Fish Wealth Muscat Proj Final Rep, vol II, pp 126-167

Herring PJ, Fasham MJR, Weeks AR et al (1998) Across-slope relations between the biological populations, the euphotic zone and the oxygen minimum layer off the coast of Oman during the southwest monsoon (August, 1994). Progr Oceanogr 41:69-109

Huang C, Qi Y (1997) The abundance cycle and influence factors on red tide phenomena of Noctiluca scintillans (Dinophyceae) in Dapeng Bay, the South China Sea. J Plankton Res 19:303-318

Intergovernmental Oceanographic Comission (2013) International Indian Ocean Expedition 50th anniversary initiative (IIOE-2). Information document. IOC/INF-1310. Paris, p 1-4. http://unesdoc.unesco.org/images/0022/002268/226861e.pdf. Accessed date 30 Oct 2014

JGOFS (1996) Cast specific comments, quality assessment, analytical methods as prepared by L. Cadispoti. ftp://ftp.nodc.noaa.gov/nodc/archive/arc0022/0001155/1.1/data/0-data/docs/PI-NOTES/arabian/Codispoti-t49.htm

JGOFS Protocols (1994) http://usjgofs.whoi.edu/JGOFS_19.pdf. Accessed date 28 Nov 2014 
Joseph PV, Xavier PK (1999) Monsoon Rainfall and Frequencies of Monsoon Depressions and Tropical Cyclones of recent 100 years and an outlook for the first decades of the twenty first century., Meteorology beyond-2000, Proceedings of National Symposium Tropmet-99., 16-19 Feb 1999, Editors A.K. Bhatnagar et al. Indian Meteorological Society, Chennai, 364-371

Kim DW, Byun HR, Lee YI (2005) The long-term changes of Siberian High and winter climate over the northern hemisphere. J Korean Meteorol Soc 41:275-283

Kistler R, Kalnay E, Collins W et al (2001) The NCEP-NCAR 50-year reanalysis: monthly means CD-ROM and documentation. Bull Amer Meteorol Soc 82:247-268

Liebmann B, Smith CA (1996) Description of a complete (interpolated) outgoing longwave radiation dataset. Bull Amer Meteorol Soc 77:1275-1277

Mathews CP, Al-Mamry J, Al-Habsy S (2001) Precautionary management of Oman's demersal fishery: 2001. First International Conference on Fisheries, Aquaculture and Environment in the NW Indian Ocean. Muscat, Sultanate of Oman, Sultan Qaboos University p 41-49

McCarthy JJ, Garside C, Nevis JL (1999) Nitrogen dynamics during the Arabian Sea Northeast monsoon. Deep Sea Res II 46:1623-1664

Methods on hydrochemical investigations of the Ocean (1978) Moscow, Nauka (in Russian)

Morrison JM, Codispoti LA, Gaurin S et al (1998) Seasonal variation of hydrographic and nutrient fields during the US JGOFS Arabian Sea Process Study. Deep Sea Res II 45:2053-2101

Neff U, Burns SJ, Mangini A, Mudelsee M, Fleitmann D, Matter A (2001) Strong coherence between solar variability and the monsoon in Oman between 9 and 6 kyr ago. Nat 411:290-293

O'Brien L, Rago R (1996) An application of the generalized additive model to groundfish survey data with Atlantic cod off the Northaest coast of the United States as an example. NAFO Sci Coun Stud 28:79-95

Panagiotopoulos F, Shahgedanova M, Hannachi A et al (2005) Observed trends and teleconnections of the siberian high: a recently declining center of action. J Climate 18:1411-1422

Peňa MA, Katsev S, Oguz T, Gilbert D (2010) Modeling dissolved oxygen dynamics and hypoxia. Biogeosci 7:933-957

Piontkovski SA, Al-Jufaili S (2013) Coastal upwellings and mesoscale eddies of the western Arabian Sea: some biological implications. Int J Ocean Oceanogr 7(2):93-115

Piontkovski SA, Claereboudt MR (2012) Interannual changes of the Arabian Sea productivity. Mar Biol Res 8:189-194

Piontkovski SA, Claereboudt MR, Al-Jufaili S (2013) Seasonal and interannual changes in epipelagic ecosystem of the western Arabian Sea. Int J Ocean Oceanogr 7:117-130

Piontkovski SA, Al-Oufi HS, Al-Jufaili S (2014) Seasonal and interannual changes of sardine landings in the Sea of Oman. Mar Fish Rev 76(3):50-59

Prince ED, Goodyear CP (2006) Hypoxia-based compression of tropical pelagic fishes. Fish Oceanogr 15:451-464

Resplandy L, Levy M, Bopp L, Echevin V, Pous S, Sarma VVSS, Kumar D (2012) Controlling factors of the oxygen balance in the Arabian Sea's OMZ. Biogeosci 9:5095-5109

Saji NH, Goswami BN, Vinayachandran PN, Yamagata T (1999) A dipole mode in the tropical Indian Ocean. Nat 401:360-363

Sherman K, Alexander LM (1990) Large marine ecosystems: patterns, processes, and yields. American Association for the Advancement of Science, Washington, p 242

Shinjo R, Asami R, Huang KF, You CF, Iryu Y (2013) Ocean acidification trend in the tropical North Pacific since the midtwenteeth century reconstructed from a coral archive. Mar Geol 342:58-64

Snider R (1961) The international indian ocean expedition 1959-1964. Discov 1:114-117

Srivastava AK, Sinha KC, Ray N, De US (2000) Trends in the frequency of cyclonic disturbances and their intensification over Indian seas. Maus 51(2):113-118

Stramma L, Prince ED, Schmidtko S et al (2012) Expansion of oxygen minimum zones may reduce available habitat for tropical pelagic fishes. Nat Clim Change 2:33-37

Sundermeyer MA, Rothschild BJ, Robinson AR (2005) Using commercial landings data to identify environmental correlates with distributions of fish stocks. Fish Oceanogr 14:47-63

Susskind J, Molnar G, Iredell L (2011) Contributions to Climate Research Using the AIRS Science Team Version-5 Products. NASA. Goddard Space Flight Center. Retrieved 14 September 2011

Tomzac M, Godfrey JS (1994) Regional oceanography: an introduction. Pergamon Press, New York

Uddin S, Gevao B, Al-Ghadban AN, Nithyanandan M, Al-Shamroukh D (2012) Acidification in Arabian Gulf-Insights from pH and temperature measurements. J Environ Monit 14:1479-1482

Von Rad U, Lückge A, Berger WH, Rolinski HD (2006) Annual to millennial monsoonal cyclicity recorded in Holocene varved sediments from the NE Arabian Sea. J Geol Soc India 68:353-368

Yao F, Johns WE (2010) A HYCOM modeling study of the Persian Gulf: 1. Model configurations and surface circulation. J Geophys Res 115:C1 1017. doi:10.1029/2009JC005781

Zveryaev II (2002) Interdecadal changes in the zonal wind and the intensity of intraseasonal oscillations during boreal summer Asian monsoon. Tell 54A:288-298 